УДК 619:616.98:636.2-631

doi: $10.36359 /$ scivp.2019-20-2.40

\title{
ВИЗНАЧЕННЯ ВЕТЕРИНАРНО-САНІТАРНОЇ ОЦІНКИ МЕДУ ТА ЙОГО РІВНЯ ТОКСИЧНОСТІ ПІСЛЯ ЗАСТОСУВАННЯ КОРМОВОЇ ДОБАВНКИ “КОБАЦИН" ДЛЯ СТИМУЛЮВАННЯ СИЛИ БДЖОЛИНИХ СІМЕЙ ТА ПОРІВНЯЛЬНА ОЦНКА БЕЗПЕЧНОСТІ 3 ІНШИМИ ПРЕПАРАТАМИ
}

\author{
Д. О. Кісіль, аспірант ${ }^{8}$
}

Сумський національний аграрний університет, вул. Герасима Кондратьєва, 160, м. Суми, 40021, Україна

У статті наведені дані про проведення дослідження на визначення токсичності в меді після застосування кормової добавки «Кобаџин» для стимулювання до нарощування сили бджолиних сімей та збільшення резистентності до змішаних хвороб та інвазіям. Одним із важливих етапів розведення бджслиних сімей - че стимулювання до нарощування сили бджслиних сімей. Незважаючи на те щзо, природна їжа для бджоли дає достатню кількість мінеральних речовин та вітамінів, бджолярі роблять підгодівлю в різні періоди розвитку додаючи стимулюючі речовини. В бджільництві в якості стимулюючих препаратів використовують мінеральні солі та вітаміни, такі як: кобальт та иіанокобаламін (В12). Одним із сучасних комбінованих препаратів для стимулювання бджслиних сімей на основі кобальту, иинку та германію є “Кобацин”. Тому нами було запропоновано провести дослідження на залишків токсичності в меді та інших продуктів бджільництва.

Ключові слова: БДЖОЛОСІМ'Я, СТИМУЛЯТОР, ВЕТЕРИНАРНИЙ ПРЕПАРАТ, “КОБАЦИН”, МЕД, БДЖІЛЬНИЦТВО, ТОКСИЧНІСТЬ.

В наш час численні дослідження показали, що при недостатньому отриманні мікроелементів для організму тварин відмічаються порушення обмінних процесів, що призводить не тільки до швидкого зниження продуктивності, а i до розладів, що в свою чергу можуть призвести до летального результату. Біологічна активність деяких мікроелементів, як відомо, аргументуються тим, що вони входять до складу структуризації організму, та зокрема до складу ферментів і гормонів. Попередньо встановлено, що каталази містить залізо, в карбангідразе міститься цинк, та в інсуліні - кобальт і нікель. Тому цим і пояснюється приближеність мікроелементів до вітамінів в організмі своєю роллю. В даний час накопичений досить багатий матеріал, щодо відношення біологічної ролі мікроелементів до організму медоносної бджоли. А. Очеретний (2016), Н. Кривцов (2017). С. Петренко і I. Петренко (2018) відмічають, що при додаванні до цукрового сиропу солей кобальту для підгодівлі бджіл, в мікродозах збільшується кількість запечатаного розплоду в бджолиних сім'ях та досить стрімко підвищується їх продуктивність. Також відмітимо що, попередніми дослідниками було встановлено що, кобальт позитивно впливає на синтез вітамінів А, E, С, В12 в організмі комах. Зареєстрований максимальний час такого синтезу фактично 96 годин. Крім того кобальт також бере участь в кровотворенні, синтезі нуклеїнових кислот, м'язових білків, підтримує тканинне дихання тощо. Він входить до складу ферментативних систем, що регулюють білковий, вуглеводний і мінеральний обмін. Підтримує організм бджоли в мінеральному живленні, особливо у весняний та осінній періоди.

Цей елемент $є$ активним учасником внутрішньоклітинного виробництва м'язового білка, полінуклеатидів, забезпечує підтримку кисневим окислювально-відновним процесам.

${ }^{8}$ Науковий керівник - Т. І. Фотіна, д-р вет. наук, професор 
Також $є$ частиною ферментних систем, які відповідають за регулювання білкового, мінерального, вуглеводного обміну. Практика застосування підгодівлі, куди додавалися таблетки кобальту, довела її ефективність щодо щільності розплоду. Таким чином в результаті ранньовесняної підгодівлі бджолосім'ї змогли збільшити цей показник на 27 $\%$, а в осінній сезон потомства було вирощено більше на $12 \%$. Виходячи з вищевикладеного матеріалу, ми поставили собі за мету вивчити сучасні стимулюючі препарати для бджолиних сімей на основі кобальту та їх ефективність.

Мета досліджень. Постає на визначенні рівня токсичності меду після застосування кормової добавки «Кобацин» для стимулювання до нарощування бджолиної сім'ї та підвищення резистенції до збудників хвороб бджіл змішаної форми.

Матеріали і методи. Попередньо, після ретельного весняного огляду, ми, підбирали бджолині сім’ї подібні між собою, під час якого ми визначали показники, які характеризують рівень розвитку бджолиних сімей, а саме: силу, кількість меду та пилку в бджолиних гніздах, кількість запечатаного розплоду бджолиних сімей. Бджолині сім ї були розміщені у в 10 -тирамкових «Дадановських» вуликах. Після відбору 9 бджолосімей, ми розділили на 3 групи: 1шу - застосовували препарат “Стартовіт”, склад якого: натрію хлорид - 0,43г, кобальту хлорид - 0,019г, динатрію фосфат - 0,1г; 2-гу - “Кобацин”, склад якого: кобальт - 0,4 мг, цинк 0,8 мг, германій - 0,08 мг; 3-тю - “Кобальт Хлористий”, склад якого: хлористий кобальт - 0,4г та натрій хлористий - 9,96 г. Проби меду піддавалися нами органолептичним та лабораторним дослідженнями. Під час органолептичному дослідженні нами було визначено колір, консистенцію, смак та запах. За допомогою металево-латунної сітки ми визначали механічні домішки. При проведенні лабораторних досліджень ми визначали вміст води, загальну кислотність, діастазну активність та токсичність меду. Проби меду та воску витримували в закритому скляному посуді в умовах побутового холодильника (температура $\left.+4-7^{\circ} \mathrm{C}\right)$. Рівень токсичності меду визначали на білих мишах, яким підшкірно вводили по 1 мл. 50 \%-ий розчин меду. За лабораторними тваринами спостерігали на протягом 5-ти діб. Та окрім того визначали токсичність й на самих бджолах. Для даного дослідження відбирали молодих бджіл. Для цього з бджолиної сім'ї відбирали соторамку з печатним розплодом (19- 21 днів) на виході молодих бджіл. Дорослих бджіл попередньо струшували у вулик, а саму соторамку поміщали у скляну касету, яку далі ставили у термостат (34-36 ${ }^{\circ} \mathrm{C}, 3$ відносною вологістю 65-75 \%). Потім однакових за часом виходу бджіл пересаджували в ентомологічні сауни. У верхній отвір ставили перевернуту уверх дном скляну банку, в який був дослідний мед які попередньо оброблені стимулюючим препаратами. Підгодовували бджіл весною, після обльоту, влітку після відкачки меду та восени, додержуючи погодних умов, які дозволяли робити заготівлю кормової бази та формування бджолиного гнізда до зимування. Препарат «Стартовіт». Застосовували у вигляді суміші: 5 г, додавали в 10 л теплого $\left(+30-35{ }^{\circ} \mathrm{C}\right)$ цукрового сиропу $(\mathrm{y}$ співвідношенні вода/цукор - 1:1). Суміш в кількості 500 мл/1 бджолосім'ю згодовували 3 рази 3 інтервалом 3 дні. Препарат «Кобацин», застосовували у вигляді суміші: 5 мл розчину додавали до 1 л теплого цукрового сиропу (вода/цукор - 1:1). Суміш згодовували 3 рази 3 інтервалом 3 дні у дозі 500 мл/1 бджолосім'ю. «Хлористий кобальт», застосовували 3 розрахунку 10 г/20 л цукрового сиропу. Препарат розчиняли в теплому сиропі. Згодовували 500 мл/сім'ю 3 рази з інтервалом 3 дні.

Результати й обговорення. Від бджолиних сімей, які піддавалися експерименту, нами було відібрані проби меду для дослідження його якості та безпечності. При органолептичному дослідженні меду було встановлено що, колір меду коливався від світло-янтарного до темнокоричневого та залежав від посіву культур та часу збирання нектару. Аромат і смак проб меду був приємний, без стороннього присмаку. Консистенція в'язка - на шпателі залишалась значна кількість меду, який стікав великими краплями. Результати вивчення фізико-хімічних показників проб досліджуваного меду показані в таблиці 1. 
Фізико-хімічні показники меду

\begin{tabular}{|c|c|c|c|}
\hline Показники & $\begin{array}{c}\text { Проба № 1 } \\
\text { (застосований стартовіт) }\end{array}$ & $\begin{array}{c}\text { Проба № 2 } \\
\text { (застосований кобацин) }\end{array}$ & $\begin{array}{c}\text { Проба № 3 (застосований } \\
\text { кобальт хлористий) }\end{array}$ \\
\hline Вода \% & 19 & 18 & 20 \\
\hline Інвертний цукор, \% & 72 & 71 & 41 \\
\hline Сахароза, \% & 5 & 5 & 5,5 \\
\hline Діастазне число, од. Готе & 5,5 & 5,4 & 3 \\
\hline Загальна кислотність & 2 & 3 & Домішки чистих бджіл \\
\hline Механічні домішки & \multicolumn{3}{|c|}{} \\
\hline
\end{tabular}

При дослідженні на механічні домішки ми відмітили що, були дрібні частинки загиблих бджіл та залишки стільників, на поверхні меду утворився шум. Відносна вологість досягла 18 - 20\%. Інвертований цукор складав 71-73 \%. Сахароза 4-5 \%, діастазне число 4 - 5 од. Готе. Загальна кислотність була у параметрах норми $-2-3{ }^{0} \mathrm{~T}$.

Таким чином, доведено, що у всіх пробах меду, незалежно від того, які імуностимуляторами згодовували бджолиним сім'ям, органолептичні і фізико-хімічні показники дослідного меду відповідали нормі. При дослідженні на токсичність меду на білих мишах та на самих бджолах, нами було встановлено що, мед з залишками стільників не був токсичний для білих мишей та бджіл. Представлено на таблицях 2 та 3. Як ми бачимо з таблиці 2, загибель мишей при введенні проб меду складала $0 \%$. Дослідний мед, який був застосований на білих мишах виявився цілком безпечний для дослідних тварин. При згодовуванні проб досліджуваного меду бджолам, який був отриманий від сімей яким згодовувалися кормові добавки, відмічали, що на життєвий цикл комах фактично не впливає дослідний мед. Смертності не реєструвалося.

Таблиия 2

Результати виявлення токсичності проб меду на білих мишах

\begin{tabular}{|c|c|c|c|c|c|}
\hline \multirow{2}{*}{ Проби меду } & \multicolumn{4}{|c|}{ Білі миші } \\
\cline { 2 - 6 } & \multirow{2}{*}{\begin{tabular}{c} 
кількість \\
\cline { 3 - 6 }
\end{tabular}} & \multicolumn{2}{|c|}{ в догинуло } & $\%$ & \multicolumn{2}{c|}{ вижило } \\
\cline { 3 - 6 } & 5 & 0 & 0 & 5 & 100 \\
\hline Проба № 1 (Стартовіт) & 5 & 0 & 0 & 5 & 100 \\
\hline Проба № 2 (Кобацин) & 5 & 0 & 0 & 5 & 100 \\
\hline Проба № 3 (Кобальт хлористий) & &
\end{tabular}

Доведено що, фактично всі препарати є безпечними як для дослідних тварин та комах - білих мишей, та самих бджіл. Поодинокі випадки смертності, ми не враховували, так як. Дослідні комахи були не в природному середовищі, томі і смертність комах які вишли с комірок розплідної рамки та не мали можливості «облетілися» як в природних умовах, будуть реєструватися до 1-2\%. При вивченні залишків стимулюючих препаратів в продуктах бджільництва ми встановили, що залишки усіх стимулюючих препаратів залишалися тільки протягом 6 місяців Стартовіт в межах від 0,1-0,22 мг/кг збереглися в меді на початкових рівнях протягом 6 місяців.

Таблиия 3

Виявлення токсичності меду на бджолах

\begin{tabular}{|c|c|c|c|c|c|c|c|c|c|c|c|}
\hline \multirow{2}{*}{ Проби меду } & \multirow{2}{*}{$\begin{array}{c}\text { Кількість } \\
\text { бджіл }\end{array}$} & \multicolumn{10}{|c|}{ Загинуло через декілька днів, а саме: } \\
\hline & & 11 & 22 & 23 & 34 & 45 & 56 & 67 & 78 & 89 & 110 \\
\hline Проба № 1 (Стартовіт) & 100 & 00 & 10 & 10 & 11 & 20 & 20 & 10 & 02 & 00 & 02 \\
\hline Проба № 2 (Кобацин) & 100 & 00 & 00 & 00 & 80 & 1 & 20 & 10 & 10 & 31 & -2 \\
\hline Проба № 3 (Кобальт хлористий) & 100 & 0 & 0 & 0 & 2 & 0 & 0 & 0 & 1 & 0 & 3 \\
\hline
\end{tabular}

Кобацин реєстрували в пробах меду протягом 6 місяців, незалежно від умов зберігання в межах 0,03 - 0,15 мг/кг меду. Залишки Кобальту Хлористого знаходили також потягом 6 
місяців в межах 0,2-0,25 мг/кг. Після залишки всіх препаратів були вже повністю відсутні, i їх наявність в пробах меду в послідуючий час не відмічалися. Про що й можна судити 3 таблиці 4.

Залишки стимулюючих препаратів (мг/кг) в пробах меду при зберіганні

\begin{tabular}{|c|c|c|}
\hline \multirow{2}{*}{ Показники } & \multicolumn{2}{|c|}{ Залишки акарицидів при зберіганні меду, мг/кг } \\
\hline & 6 місяців & 12 місяців \\
\hline Стартовіт & & \\
\hline $\mathrm{t} 4-6 \mathrm{C}$ & 0,1 & Н/д \\
\hline t $18-22 \mathrm{C}$ & 0,2 & H/д \\
\hline $\mathrm{t} 34-36 \mathrm{C}$ & 0,22 & Н/д \\
\hline Кобацин & & \\
\hline t 4-6 C & 0,03 & Н/д \\
\hline $\mathrm{t} 18-22 \mathrm{C}$ & 0,05 & $\mathrm{H} /$ д \\
\hline t 34-36 C & 0,15 & Н/д \\
\hline Кобальт Хлористий & & \\
\hline t $4-6 \mathrm{C}$ & 0,2 & Н/д \\
\hline t $18-22 \mathrm{C}$ & 0,2 & Н/д \\
\hline t $34-36 \mathrm{C}$ & 0,25 & H/д \\
\hline
\end{tabular}

Таким чином, можна сказати, що препарат «Кобацин», як і інші аналогові засоби, є не тільки ефективним препаратом при стимулюванні нарощування бджолиних сімей, але й досить безпечною речовиною. Мед, отриманий від бджіл, не $\epsilon$ токсичним для лабораторних тварин і через 6 місяців не містить залишків препарату.

\section{В И С Н О В К И}

Попередніми дослідами нами було доведено, що препарат «Кобацин»є ефективний стимулятором до нарощування сили бджолиних сімей. За вище вказаними результатами дослідження відмітимо що, даний препарат практично безпечний для лабораторних тварин, тому и для людей також.

Перспективи досліджень. У подальшому планується впровадити у виробництво препарат «Кобацин», який може успішно застосовуватись у бджільницькій практиці у весняний та осінній періоди, як засіб для стимулювання нарощування сили бджолиних сімей та збільшення резистентності до збудників змішаних хвороб бджіл.

\section{DETERMINATION OF VETERINARY - SANITARY ASSESSMENT OF HONEY AND ITS LEVEL OF TOXICITY AFTER THE APPLICATION OF FOOD ADDITIVE "KOBACIN" FOR STIMULATION THE POWER OF BEEES FAMILIES AND COMPARATIVE SAFETY ASSESSMENT WITH OTHER ANALOGES}

$$
\text { D. O. Kisil }
$$

Sumy National Agrarian University, st. Gerasima Kondratyeva, 160, m. Sumi, 40021, Ukraine

\section{S U M M A R Y}

The article presents data on the research on the determination of toxicity in honey after the use of the feed supplement "Cobacin" to stimulate the growth of the strength of bee families and increase the resistance to mixed diseases and invasions. It should be noted that, according to statistics and own research, there was a rather rapid tendency in the development of beekeeping in our country. Since, 
the main function of beekeeping in Ukraine is pollination of entomophilic plants of agricultural purpose. Known to us as: sunflowers, mustard, garden trees and others. We also know that the beekeeping industry, of course, receives well-known beekeeping products, such as: honey, pollen, perg, propolis, wax and uterus milk, and others. Which are used both in the medical sphere, I have dietary foods, as well as cosmetology. Over the past few years, honey production in the country has grown by over $25 \%$. As far back as 2017, Ukraine became one of the three main exporters of honey in the world, where Ukraine's share in global total exports of honey in 2017 accounted for more than $10 \%$, while the top three export-export leaders accounted for about $40 \%$ of total exports. Therefore, in our time beekeeping can not exist in the modern market without high profitability. High profitability includes a large set of conditions, which in turn includes the health of bees. Healthy bees - this is one of the conditions for a good liveliness, rapid spring development and high honey assemblies. One of the main tasks in beekeeping is to increase the strength and productivity of bee families. One of the important stages of breeding bee families is to stimulate the growth of the strength of bee families. Despite the fact that natural bee food gives enough minerals and vitamins, beekeepers make feeding in different periods of development by adding stimulants. In beekeepers, mineral salts and vitamins such as cobalt and cyanocobalamin (B12) are used as stimulants. "Kobacin" is one of the modern combined preparations for stimulation of cobalt, zinc and germanium bee families. Therefore, we were asked to conduct a study on residues of toxicity in honey and other bee products.

Keywords: BEE FAMILIES, STIMULATOR, VETERINARY DRUG, KOBACIN, HONEY, BEEKEEPING, TOXICITY.

\title{
ОПРЕДЕЛЕНИЕ ВЕТЕРИНАРНО - САНИТАРНОЙ ОЦЕНКИ МЕДА И ЕГО УРОВНЯ ТОКСИЧНОСТИ ПОСЛЕ ПРИМЕНЕНИЯ КОРМОВОЙ ДОБАВКИ "КОБАЦИН" ДЛЯ СТИМУЛИРОВАНИЯ СИЛЫ ПЧЕЛИНЫХ СЕМЕЙ И СРАВНИТЕЛЬНАЯ ОЦЕНКА БЕЗОПАСНОСТИ С АНАЛОГОВЫМИ ПРЕПАРАТАМИ
}

\author{
Д. А. Кисиль \\ Сумской национальный аграрный университет, \\ ул. Герасима Кондратьева, 160, Сумы, 40021, Украина
}

А Н Н О Т А И Я

\begin{abstract}
В статье приведены данные о проведении исследования на определение токсичности в меде после применения кормовой добавки «Кобацин» для стимулирования к наращиванию силы пчелиных семей и увеличение резистентности к смешанным болезней и инвазиям. Одним из важных этапов разведения пчелиных семей - это стимулирование к наращиванию силы пчелиных семей. Несмотря на то, естественная пища для пчелы дает достаточное количество минеральных веществ и витаминов, пчеловоды делают подкормку в разные периоды развития добавляя стимулирующие вещества. В пчеловодстве в качестве стимулирующих препаратов используют минеральные соли и витамины, такие как: кобальт и цианокобаламин (В12). Одним из современных комбинированных препаратов для стимулирования пчелиных семей на основе кобальта, цинка и германия является "Кобацин". Поэтому нами было предложено провести исследование остатков токсичности в меде и других продуктов пчеловодства.

Ключевые слова: ПЧЕЛОСЕМЬИ, СТИМУЛЯТОР, ВЕТЕРИНАРНЫЙ ПРЕПАРАТ, "КОБАЦИН", МЕД, ПЧЕЛОВОДСТВО, ТОКСИЧНОСТЬ.
\end{abstract}




\section{Л I T E P A T Y P A}

1. Еськов Е. К. Экология медоностной пчелы. - Ветеринарная медицина. - 2013. - С. 123 $-334$.

2. Гробов О. Ф. Болезни и вредители медоносных. - Агропромиздат. - 2011. - С. 134 333.

3. Руденко E. B. Опыт организации ветеринарных мероприятий в крупных пчеловодческих хозяйствах. - Ветеринарная медицина. - 2012. - С. 521-526.

4. Лучко М. А. Болезни расплода пчел. - Ветеринария. - 2012. - С. 9-14.

5. Оненко В. I. Присадибне бджільництво. - Бібліотека ветеринарної медицини. - 2011. - C. 34 - 112.

6. Полтораикая P. С. Применение природних фунгистатиков для создания препаратов против аскофероза. - Эффективные и безпасные лекаоственные средства в ветеринарии. 2012. - C. 221-224.

7. Кісіль Д. О. вплив препарату «кобацин» на продуктивні показники бджолиних сімей //Ветеринарна біотенологія: бюлетень. - К. Вид-во ДНКІБШМ - 2013. Вип. 32(1) С. 351-356.

8. Руденко $C$. В. Біологічні препарати в системі заходів профілактики та ліквідації інфекційних хвороб бджіл. - Ветеринарна медииина Украйни. - 2012. - С. 42-43.

9. Березовський А. В. Нозематоз - як проблемна хвороба бджолосімей. - Украӥнський пасічник. - 2012. - С. 22-24.

\section{References}

1. Es'kov YE. K. (2013), "Ecology of honey bee" // Veterynarna medytsyna. - 2013. -P.123 334. (in Russian) Ukrainian)

2. Hrobov O.F. "Diseases and pests of melliferous" // Ahropromyzdat -2011 -P.134 -333. (in

3. Rudenko E.V. "Experience in organizing veterinary activities in large beekeeping farms" // Veterynarna medytsyna. - 2012 -P.521-526. (in Ukrainian)

4. Luchko M.A. Diseases of brood bees // Veterynariya. - 2012 -P.9-14. (in Ukrainian)

5. Onenko V.I. Indigenous beekeeping // Biblioteka veterynarnoyi medytsyny. -2011 -P. 34 112. (in Ukrainian)

6. Poltoratskaya R.S. The use of natural fungistatics to create drugs against ascopherosis // Éffektyvnye y bezpasnye lekaolohycheskye sredstva v veterynaryy. - 2012 - P. 221-224. (in Russian)

7. Kisil D.O. Effect of the drug "cobacin" on the productive indices of bee families // Veterinary Biothenology // Bulletin. - K.: View of DNKIBSHM - 2013. № 32 (1) - P. 351-356. (in Ukrainian)

8. Rudenko YE.V. Biological drugs in the system of measures for the prevention and elimination of infectious diseases of bees // Veterynarna medytsyna Ukrayiny. - 2012 - P. 42-43. (in Ukrainian)

9. Berezovs'kyy A. V. Nosematosis - as a problem illness of bee-eater // Ukrayins'kyy pasichnyk. -2012 -P. 22-24. (in Ukrainian)

Рецензент - А. В. Березовський, д. вет. н., професор, Сумський НАУ. 